\title{
EFFECT OF DIVIDEND POLICY ON STOCK PRICES
}

Ilyas Sharif ${ }^{1}$

Adnan $\mathrm{Ali}^{2}$

Farzand Ali Jan ${ }^{3}$

\author{
Başvuru Tarihi: 01.01.2015 \\ Kabul Tarihi: 21.01.2015
}

\begin{abstract}
This investigates the effect of dividend policy on stock prices. Objective of the study is to see if there exists any relationship between dividend policy and stock prices. We analyzed 45 non-financial companies listed on KSE-100 index that have earned profits and paid dividend for a period of twelve year w.e.f. 2001. Technique adopted for sampling adopted is convenience sampling. As the nature of data is panel therefore, pooled regression, fixed and random effect tests are run. Random effect results are focused after applying Hausman's test.Regression Results witness that Dividend per Share andRetention Ratio havean insignificant relationship with Share Market Prices.Dividend Payout Ratio has a significant positive relationship with Share Prices as supported by the Bird in hand theory suggested that owners give preference to a dollar of estimated dividends over a likely dollar of capital gains. Profit after tax, Earning per share and Return on Equity are the three control variables. Profit after Tax has insignificant relation to Stock Prices. Earnings per Share have positive significant relation to Stock Prices. There is negative significant relation between Return on Equity and Share Prices. It is recommended that firms in the sample should regularly pay dividend as it will cause an upward movement in the stock market prices. Whereas profit retention by firms will result in a decrease in the value of the stock market prices.
\end{abstract}

Keywords: Dividend Policy, Stock Prices

JEL Codes: G10

\section{KÂR DAĞITIM POLITIKKASININ BORSA FIYYATLARI ÜZERINE ETKİSİ}

$\ddot{O Z Z}$

Kar dağıtım politikasının borsa fiyatları üzerine etkisini incelemektedir.Çalışmanın amacı,kar dağıtım politikası ve borsa fiyatları arasında herhangi bir ilişkinin var olup olmadiğını görmektir. 2001den itibaren 12 yıllık bir periyot için kazanılan karlar ve ödenen kar paylarına sahip olan KSE-100 indeksinde listelenmiş olan 45 tane finansal olmayan firmayı analiz ettik.Örnekleme için benimsenen teknik uygun örneklemedir.Bilginin doğası panel olduğu için, toplanmış regresyon,sabit ve rastgele etki testleri uygulanır. Hausman'in testinin uygulanmasının ardından rastgele etki sonuçlarına yoğunlaşılır.Regresyon sonuçları, Bird tarafindan, sahipler ödeme önceliğini bir dolarlık tahmin edilen kar dağıtım oranından çok bir dolarlık sermaye kazancına verirler iddiasını öne süren el teorisinde desteklendiği gibi her hisse için kar dă̆ıtma ve dă̆ıtmama oranlarının hisse

\footnotetext{
${ }^{1}$ Instutite of Business and Management Sciences, The University of Agriculture, Peshawar

${ }^{2}$ Asisst. Prof., Deparment of Management Sciences (SBBUS), adnanmsd1458@gmail.com (Corresponding author)

${ }^{3}$ Prof. Dr., Comsats University of Technology, sevdam91@ hotmail.com
} 
senedi piyasası fiyatlarıyla önemli düzeyde bir ilişkisinin olmadı̆̆ını, kar dă̆ıtım ödeme oranının hisse senedi fiyatlartyla önemli düzeyde pozitif bir ilişkisinin olduğunu göstermiştir.Vergiden sonraki kar,her bir hisse için kazanç ve özsermaye karlılık oranı 3 tane kontrol değişkenidir.Vergiden sonraki kar ile stok fiyatları arasında önemsiz bir ilişki vardır.Her bir hisse için kazançlar ile stok fiyatları arasında önemli düzeyde pozitif bir ilişki vardır.Özsermaye karlılı oranı ve hisse fiyatları arasında önemli düzeyde negatif bir ilişki vardır.Borsa fiyatlarında yukarı yönlü bir harekete sebep olacă̆ı için örneklemdeki firmaların kar dağıtım paylarını düzenli olarak ödemeleri gerektiği yorumu yapılır.Oysa firmalar tarafindan dağıtılmamış kar, borsa fiyatlarının değerinde azalma ile sonuçlanacaktır.

Anahtar Kelimeler: Kar Dağıtım Politikası, Borsa Fiyatları

JEL Kodlar1: G10

\section{INTRODUCTION}

Dividend policy has been among the very important topics in financial management since the coming into existence of Corporation form of business. East India company was the very first J.S. Company ever in history of the world to issue shares in 1613 and declare dividend in 1661 (Davis 1917). Later on payment of dividend was started and rules for dividend policy developed. Lintner (1956) was pioneer to work on dividend policy. He inquired about the factors that affect the size, shape and dividend payment timing. Later on Miller and Modigliani (1961) found that there exists no relationship between the dividend and the value of any firm; rather investment policy can exclusively affect the value of the firm. Gordon (1963) proved that dividend policies cause a change in the firm value and is an indication for the prospectincomes (Baskin, 1989). Many hypothetical systems have been proposed that shows an inverse relationship of dividend yield and payout ratios with common stock volatility. Dividend policy affects a number of things, e.g. duration, rate of return, arbitrage pricing along with information effect. However, this study focuses on "Impact of dividend policy on stock price." According to duration effect high dividend yield provides short term cash flow. In case of stable dividend policy dividends, stock will have a short term duration. As per Gordon Growth Model predictions, more dividend will show less response to changes in the value of discount rates and as a result show the lower price explosiveness.

\subsection{Background of the Study}

Despite of a lot of theoretical and practical work in the field of finance "Dividend Policy" has been a debatable topic for a long time among the professionals, writers, researchers and academicians. Managers make decisions that how much dividend should be paid and when? While shareholders plan their own assetcollection. Dividends may simply termed as acause of income for investors and works as an indication of business performance. 
Through dividend policy managers make a choice about the utilization of profit between dividend and retained earnings. Selection of a suitable dividend policy for a company is extremely important decision for the management and owners of the company.

\subsection{Dividend Policy world-wide}

Jensen and Meckling (1976) established Agency Cost Argument; that dividend payment decreases costs of an organization and grows its cash flow. In simple words, dividends payment encourages managers to throw out cash rather than making an investment at less than cost or its wastage on managerialinadequacies,(Rozeff, 1982; and Easterbrook,1984). Many scholars have given stress on the significance of dividend statistics on stock prices and or stock returns. Asquith \& Mullin (1983); Born et al., (1983). Miller and Rock (1985) recommended that dividend declaration give the omitted facts about the business and as a result market may guesstimate the corporation'sexisting earnings. Shareholders have better assurance that economic profits are reported when announcements are followed by sufficient dividends. If investors have confident opinions, they may respond less to less authentic information.

Stock prices may become more responsive to fluctuating predictions of degrees of profitin excess of remote time phases.Gorden (1963) worked on rate of return effect and found thatfirms having less payout and less dividend yield ratios are appreciated for future investment opportunities. That is why despite having lower payout and dividend yield ratios growing firms maintain stable stock prices. Besides other, reasons may include that these ratios serve as an indication of projected growth opportunities. Growing firms are those firms that have not yet attained the maturity level rather still have opportunities for growth. On the other hand assets in place are the firms which are at their maturity level having no or less developmentprospects. If projections of revenues from growing chances become less consistent than estimates of incomes on assets in place corporations with little payout and dividend ratiosmay possibly have more price elasticity. As per duration and arbitrage effects payout ratio is not an appropriate gauge rather the dividend yield is. Rate of return outcome shows both dividend yield and payout ratios are important. Dividend Policy gives an idea for growth and investment opportunities.

Baskin (1989) checked the effect of dividend policy on stock price volatility. It is difficult to practically see whether there exists any relationship between dividend policy and stock unpredictability because acceptable controls intended for other elements should be 
established. For instance, the system of accounting provides information on many affiliations; assumed to be a measurement of risk. Baskin (1989) used operating incomes, the magnitude of the business, debtto equity ratio, payout ratio and the respective firm's growth as control variables in checking the impact of association between dividend yield and price explosive nature. These variables affect stock returns and also dividend yield. Kaen (2003) says that the managementpurpose of maximization of shareholders' wealth is itself an end-it is the ways to the single-mindedness of well-organizedallocation of resources and economic growth.

\subsection{Dividend Policy in Pakistan}

Karachi Stock Exchange (KSE) is one among the budding marketplaces of the emergingnations. At KSE, investors face great risk and get a high return by getting a more risk premium (Nishat, 1999). Limited studies have been conducted to check the long lastingconduct of the market and also the related issues (Nishat, 1991, 1992, 1995, 1999, 2001); (Nishat and Bilgrami, 1994) but the significance of dividend yield and payout ratio on the value of stock prices has been an undiscovered area.

It is significant to check its role in Pakistan nextto the opening of improvements during the decade just preceding to $21^{\text {st }}$ century, that stressed on the openness to foreign investment and rivalry, which moved to greater than before instability in the market (Nishat, 1999) and also has decreased sensitivity of share price unpredictability to elementary factors (Irfan and Nishat, 2003). Improvements relating to dividend policy in Pakistan are; tax sealing over the payment dividend in form of cash, declaring exemption for taxation of right and bonus shares, outline changing from the payment of dividend in the form of cash to issue of bonus share and government guiding principles of simplification limits on movement of market profits.

\subsection{Problem Statement}

The main purpose of financial management is the maximization of shareholders' wealth with a clear balance in three core decisions namely, investment, financing and dividend decisions. Dividend decisions being the basis for dividend policies, is the main purpose and focus of the study, moves around the determination of the payout policy followed by management in determining the amount along with method of cash allocations to shareholders. In this study the affiliation between dividend policy and stock prices is measured using multiple regression analysis. 
Nazir et al., (2010) studied the role of dividend policy in Pakistan while selecting 73 firms listed in KSE for a duration of six years with effect from 2003. Khan (2011) studied 202 Pakistani enterprises listed on KSE for a period of five years starting from 2005. In his research study, he used event study for computing share returns around dividend announcements. He interviewed 23 companies' executives and 16 financial analysts to find out the determinants of dividend policy and the role of dividends as a market signal. Kanwal (2011) considered fifty five companies that were listed on the Karachi Stock Exchange-100 index, Business Recorder and State bank of Pakistan for a duration consisting of 10 years starting from 2001. In my study sample is composed of 45 non-financial firms listed on KSE100 index. This sample is observed for twelve years starting from 2001. Fixed and Random effects of Regression Analysis are used in this study.

Dividend policy is important for both the management and stockholders, because one group has to decide and make arrangement for the payment of dividend while the other group has to receive it as a reward for their investment. Dividends are a source of income for investors as well as a representation of the performance of the company. Deciding a proper dividend policy becomes a main decision for managers and investors. Shareholders like both receiving of dividend and increase in the earnings per share of the company which is only possible by the reinvestment of earning profits in the company. If a major portion of the profits earned is reinvested then payment of a satisfactory level of dividend will not be possible. On the other hand if a major portion of the profits earned by a firm is distributed in the form of dividend then reinvestment of profits at a reasonable level will not be possible. A tradeoff is involved between the amount of dividend disbursements and reinvestments out of the profits earned by a firm. A balanced policy approach is thus very important for this purpose.

Dividend policy is a financial policy all about for the utilization of profits earned by a firm. It simply guides the management regarding the ratio of payment of dividend and reinvestment of the profits of the firm. Dividend irrelevance theory states that shareholders are not too much concerned with the firm's dividend policy as they can easily sell out some of their shares if they are in need of cash. This theory shows that dividend payment has little to no impact on stock price. Residual, stability and hybrid are the three main dividend policies. The residual dividend policy allows dividend payments after meeting all project capital requirements. This policy is mainly used by all those firms which try to keep a balance between their debts to equity ratio. With the help of dividend stability policy, quarterly 
dividends are paid as fraction of annual earnings. As a result uncertainty of owners may decrease as they get the revenue. This policy is mostly used by firms which pay firms' earnings to owners rather than making further investments. Hybrid dividend policy is a blend of residual and stable dividend policy. Dividend policy is commonly used approach by a majority of dividend paying firms. Firms using this approach, consider debt to equity ratio as a goal. Firms using this approach normally have one set dividend that may be paid easily being a minor part of annual firms' income. Additional dividend is paid in case income crosses general levels.

\subsection{Scope of the Study}

The study covers non-financialorganizations listed in Karachi Stock Exchange aimed at a period of 2001 to 2012. This study focuses on Pakistani companies. Initially, all nonfinancial firms listed in KSE-100 index were selected. Then, due to non-availability of data some of those firms were removed from analysis. Further, only those firms were selected for sample which had earned profits and distributed dividends throughout the period of study from 2001 till 2012. As a result sample comprised of 45non-financial companies from KSE100 Index for a period of twelve years w.e.f. 2001. Kanwal (2011) also used a sample of fifty five companies for ten years starting from 2001. Variablesof the current study include stock dividend per share, retention ratio, profit after tax, earnings per share, return on equity and stock market prices. Panel data technique was applied, using fixed effect and random effect models. The leading limitation of this study may be that there might be any othercomparatively better model that may not be in the knowledge of the researcher and could be used instead.

\subsection{Research Questions}

- Does dividend policy haveany impact on stock prices?

- Is there any relationship between dividend policy factors and stock prices?

\subsection{Objectives of the Study}

- To study if there is any relation between dividend policy factors and stock prices?

\subsection{Hypothesis}




\subsubsection{Hypothesis One:}

$\mathrm{H}_{0 \mathrm{a}}$ : Stock Dividend Policy insignificantly affects Stock Prices.

$\mathrm{H}_{1 \mathrm{a}}$ : Stock Dividend Policy significantlyaffects Stock Prices.

\subsubsection{Hypothesis Two:}

$\mathrm{H}_{0 b}$ : Retention Ratio insignificantly affects Stock Prices.

$\mathrm{H}_{1 b}$ : Retention Ratio significantly affects Stock Prices.

\subsubsection{Hypothesis Three:}

$\mathrm{H}_{0 c}$ : Dividend Payout Ratio insignificantly affects Stock Prices.

$\mathrm{H}_{1 \mathrm{c}}$ : Dividend Payout Ratio significantly affects Stock Prices.

\section{LITERATURE REVIEW}

Dividend Policy is simply a firm's guiding principle and company's option either to pay dividend to its owners or to retain a share out of profits to plough back in the firm. Numerous studies have already been carried out to put in plain words the bond amid dividend policy and stock prices. Preceding studies on this topic supply a well-built support for the incidence of an association between dividend policy and share prices. Though Dividend Policy is extensively researched topic in the area of Finance, but at the same time it is arguable and center of attention of researchers to discover its new scope.

Lintner (1956) was the pioneer to observe the impact of dividend policy on share prices. He studied diversified factors of firm dividend policy along with its consequences on the value of Firm's market by interviewing executive level management of 28 companies. The results of his research pointed out that Firm's Market value is affected by Dividend Payout. Dialogue of Dividend Policy remains incomplete without mentioning the vital input of Miller \& Modigliani (1961) who presented the idea of Dividend Irrelevance. Their study gave the results that dividend policy does no influence firm's worth; the value of a firm changes exclusively due to firm's investment policy or earnings. Dividend Irrelevance Theory was founded keeping in view conditions of perfect market, no taxes, zero transaction cost or unequal information and no initiation cost. This theory was experienced by several researchers. Gordon and Shapiro (1963) presented another analysis of the dividend policy through introducing the theory of dividend relevance. They held that dividend policy shapes the value of firm and stock prices at the same time. They stated that owners of shares are 
usually risk reluctant and wish to have current and steady returns. In other words they have a preference for dividends over capital gains.Black \& Scholes (1973) held up the Dividend Irrelevance Theory by further saying that proceeds of low and high yielding shares have no variation. Consequently profits earned by investors' leftover identical, no matter have gotten either of the securities. John \& Williams (1985) demonstrated an affirmative association between dividend policy and stock prices. They studied the investor's inclination for dividends in tax environment.Baskin (1989) after observing 2344 US common stocks for a period of ten years ranging from 1967 to 1986 calculated the blow of dividend policy on stock price explosive nature and established indirect relationship in Dividend Policy and stock prices. His outcomesrevealeda considerable association in dividend yield and price instability. Besides these factors like amount of earnings, firms' size, debt to equity ratio, level of growth and ratio of dividend payout have considerable force on returns of share and dividend yields.

Barclay and Smith (1995) concluded that rate of growing of companies has an indirect relationship with Dividend Payout and Debt Ratios. Thus investors desire more Dividend Payouts and think it's not as much of a dangerous nature as capital gain.

Allen \&Rachim (1996) established no association in dividend policy and stock prices though they observed 173 effects of Dividends on share prices. Their research outcome elaborated that dividend policy shows no impact on the value of share prices; rather it is being affected by the investor's judgment for choice of great or small yielding securities; though profit gained by stockholders in either case is same. Nevertheless the study carried out by Benartzi, Michaely and Thaler (1997), Travlos, Trigeorgis, \&Vafeas (2001), Baker, Powell \&Veit (2002), Myers \& Frank (2004), Dong, Robinson \& Veld (2005) and Maditinos, Sevic, Theriou, \&Tsinani (2007) sustain the dividend relevance theory. DeAngelo\&DeAngelo(2007) and Rashid A\& Rahman (2009) also did not hold up the Dividend Irrelevance Theory by stating that this theory is founded on impractical rules.

Ho (2002) by utilizing a panel data approach and fixed regression model demonstrated direct relationship between dividend policy and magnitude of Australian firms and ability of Japanese corporations to pay liabilities. He observed indirect association between dividend policy and risk exclusively for companies of Japan. By and large Australia and Japan have a significant industrial effect. Travlos, Trigeorgis, \&Vafeas (2001) observed direct association between dividend policy and Stock Prices who stated that Stock Prices grows with a growth in Cash Dividend and vice versa International Research Journal of Finance and Economics Issue 76 (2011) 70. 
Chen et al., (2002), Adefila, Oladipo and Adeoti (2004), Uddin and Chowdhury (2005), Denis and Osobov (2008) and Adesola andOkwong (2009) sustained Dividend Irrelevance Theory in existence of all the suppositions discussed by Miller \& Modigliani (1961).Managers have right to use to the internal information of the corporation. They distribute this information with the owners of company by preparing and publishing annual reports. Invariant or growing dividends give optimistic signals about the future projections of the corporation and as a consequence share price of the firm grow upward. Likewise in case of no dividend or declining dividends gives a pessimistic signal causing a decrease in stock prices.

Pradhan (2003) checked the effect of dividend disbursement along with retained incomes on the share price of Nepali firms and concluded that dividend payout and retained earnings ratio has a well-built association and feeble with stock prices respectively. He added that Nepalese investors prefer dividend to capital gains. Nishat\&Irfan (2003) observed 160 corporations enlisted at Karachi Stock Exhange for twenty years from 1981 to 2000 by using cross sectional regression analysis concluded a direct association between dividend yield and payout ratio with share price instability.

Adefila et al., (2004) analyzed the facts causing changes in dividend policy of Nigerian companies and concluded that Nigerian companies wish to pay dividends without any breaks and that there is no association among Net Earnings, Dividend Payments and Share prices. Nigerian companies disburse dividends to owners of the companies irrespective of the amount of incomes for the contentment of the owners.

Myers and Frank (2004) analyzed the statistics of 483 corporations from Multex Investor Database, came up with the statement that there existsa direct association of the price earnings ratio with dividend payout ratio. In addition they also noticed a momentous direct association between debt to equity ratio and dividend payout. Baker et al., (2006) studied the attitude of Norwegian management members who designed dividend policy through utilizing survey technique. The output of the survey highlighted that existing and expected earnings, constancy of earnings, present level of financial leverage, and liquidity are the important factors that management members judge in the process of scheming dividend policies. Their research outcome gave a varied judgment about the dependency of a firm's value on dividend policy. 
Anand (2008) elaborated that dividends work as a signal about the company's success and has an effect on stock prices. Capstaff et al., (2004) checked the signaling effect of dividend declaration on share prices of companies enlisted on Oslo Stock Exchange (OSE) and pointed out that the stock price has a positive association with the dividend. Studies of Travlos et al., (2001), Myers and Bacon (2004), Dong et al., (2005), Baker et al., (2002) and Maditinos et al., (2007) also confirmed the idea. Amidu (2007) checked the impact of dividend policy enlisted at Ghana Stock Exchange and firstly observed the existence of direct association between return on assets, dividend policy and growing in sales and secondly that there existsan indirect association between the values of return on assets, dividend payout ratio and leverage.

Raballe andHedensted (2008) in Denmark recognized the direct association between the values of cash dividends andcorporations' net earnings, return on equity, retained earnings, magnitude and previous year profit. They did not at all find an association of debt equity rates and dividend decision in Denmark. Denis \&Osoboy (2008) statistically tested the direction of corporations for setting dividend policy. They concluded that the common direction in the US, Canada, UK, Germany, France, and Japan is that firms with better earnings ratio and more retained incomes to total equity give dividends to the owners. Whereas firms having a lesser earnings ratio and lower retained incomes to total equity do not pay dividend or pay at a lesser rate. Whether to shell out dividends or not totally depends upon the internal and external surroundings.

Pani (2008) observed the link between dividend policy and Stock Prices by selecting 500 companies out of the six sectors of Bombay Stock Exchange and came up with the points that dividend retention ratio has direct association with stock profits. Rashid \& Rahman (2009) considered the relationship between dividend policy and stock price volatility by studying firms in Bangladesh who observed directly but not of worth mentioning relationship between stock price unpredictability and disbursement yield while monitoring factors like earning volatility, payout ratio, debt level, firm size and growth in assets.

Some researchers have totally different perception that dividend policy does not predict correctly about corporation's prospects. Ling et al., (2008), Denis andOsobov (2008), and Chen andDhiensiri, (2009) observed the features of dividend giving companies whose outcome showed that dividend policies of firms do not hint about the firm's prospects, rather shed light on firm's past performance. 
Hussaineyet al., (2011) analyzed the influence of dividend policy on stock prices who concluded a direct association between dividend yield and stock price while indirect association in the dividend payout ratio and stock prices. They also highlighted that companies' earnings, growth rate, level of leverage and magnitude also fluctuate share price of the UK. Baker \& Powell (2012) through the utilization of survey technique saw the views of Indonesian Managers regarding the points affecting dividend policy, dividend issues, and explanations for disbursing corporate profits. They concluded that Indonesian managers look at earnings' stability, level of present and prospective profits to be extremely significant elements of dividend policy.

Ahmad \&Javaid (2009) investigated the factors of dividend policy in the Pakistani rising market by selecting a sample of 320 firms enlisted at Karachi Stock Exchange for six years starting from 2001 up to 2006. The outcome of their research proved that majority of Pakistani firms make payment of dividend on the basis of present of the prior years' profits. In simple firms earning increased income distribute more dividends to their owners. Their research pointed out the direct association of market liquidity with a dividend payout ratio and indirect association between growth opportunities and dividend disbursement.

Akbar andBaig (2010) selected 79 institutions scheduled at Karachi Stock Exchange for a time span of four years starting from 2004 to realize the impact of dividend declaration on stock prices. Their research outcome proved that dividend announcement has a constructive consequence on stock prices irrespective of the fact whether the dividend is cash dividend, stock dividend or a blend of both. Naziret al., (2010) also checked the impact of dividend policy on stock prices. They concluded that stock prices note worthily depend on dividend payout and dividend yield ratios of shares, size and leverage have indirect inconsequential, whereas earning and growth have a direct momentous impacton share prices.

Khanet al., (2011) after analyzing the impact of dividend disbursement on share prices got the conclusion by observing fifty five companies scheduled at Karachi Stock Exchange that dividend yield, earnings per share, return on equity and earnings after interest and taxes have direct association, whereas retention ratio has an indirect association with stock prices.

In short dividend policy means the policy of choice in payment of dividend and profit retention that is followed by any corporation. Impact of dividend policy has always been controversial for centuries. There are basically two schools of thought on this topic; one 
considers dividend policy relevant to have a remarkable impact on stock prices, while the other consider it totally irrelevant to have an impact on stock prices. Many researchers proved either of these theories. This topic has been worked upon throughout the globe including Pakistan.

\section{Conclusion}

Though Ahmad and Javaid (2009) explored the factors of dividend policy by selecting a sample of 320 firms enlisted at Karachi Stock Exchange for six years starting from 2001. The panel character of data allows us to use the panel estimation technique. They used panel data estimations and applied the Generalized Method of Moments (GMM) as estimation technique. Akbar and Baig (2010) selected 79 firms scheduled at KSE for four years starting from 2004 to realize the impact of di vided declaration on stock prices. Khan (2011) studied the fifty five firms and used event study effect. Akbar and Baig (2010) studied seventy nine firms for four years starting from 2004.In this study latest data from 2001 to 2012 have been used. Secondly in previous studies retention ratio was mostly ignored that is included in this study.

\section{RESEARCHMETHODOLOGY}

In this chapter the selection of sample, the data collection techniques and methodology are described. Dividend policy has been one of the very many important topics in financial management since the coming into existence of joint stock companies. Panel data technique was applied, using fixed effect and random effect models. Data was collected from 45 firms listed on Karachi Stock Exchange 100-index. Beside this stata software package 12 version is used for data analysis.

\subsection{Universe of the Study}

In Pakistan there exist three stock exchanges namely Karachi Stock Exchange (KSE), Lahore Stock Exchange (LSE) and Islamabad Stock Exchange (ISE). This study concentrates upon Karachi Stock Exchange. Reason for selection of KSE is that most well-organized and leading Pakistani Stock Market. It consists of 34 sectors comprising of a total of 652 firms. The universe of the study comprises all those companies that have been listed on Karachi Stock Exchange for a period of twelve years starting from 2001 till 2012.

\subsection{Sampling Design}


Karachi Stock Exchange 100 index is composed of thirty four sectors. Out of this total nine sectors are financial and twenty five sectors are non-financial. The sample is selected out of nonfinancial sectors. The sample is composed of nonfinancial firms; listed at KSE-100 Index for the period starting from 2001 to 2012, which have a positive Net Income and made Dividend Payments. The KSE-100 Index consists of top 100 firms on the base of market capitalization.

\subsection{Data Collection}

Thisresearchisgrounded on secondary figures that iscomposed from the business recorder websites, KSE website, and annual reports of the KSE-100 Index companies and State Bank of Pakistan for 12 years' time period w.e.f. from 2001.

\subsubsection{Panel Data}

Panel data may be defined as "longitudinal data collected at different points in time." Survey of consumers and organizations' data at different points of time are examples of panel data. Panel data are usually tested, by using fixed effect and random effect models of regression analysis.

\section{a. Fixed Effect}

It is a statistical model specifically applied in regression and ANOVA with the assumption that the independent variable is fixed. Simplification of the outcomes applies to the similar values of independent variable in the population or in other studies. It checks relationship among explanatory and explained variables within an entity. For the purpose of analysis of net effect of independent variable, time invariant characteristics are removed by fixed effect model. In fixed effect case reduced standard errors will most likely be produced.

\section{b. Random Effect}

Different statistical models like regression or ANOVA accept random independent variable. This model is usually applied in situation(s) where the levels of the independent variable levels are considered a small subset of the possible values which one wish to simplify to. In random effect model the random distinction among the entities is supposed. Further it is expected that this dissimilarity uncorrelated with independent variable. Time invariant variables like gender are included in random effect model. 
Both of the above tests are applied initially. Whether to focus the results of fixed or random effect it is prerequisite to use Hausman'stest. If the P-value of the Hausman test is less than 0.05 then we will consider Fixed effect otherwise Random effect.

\subsection{Model}

In order to look at the effect of dividend policy and share price this study follows multiple regression analysis. In multiple regression analysis, the dependent variable share price is regressed against three independent variables that are stock dividend per share, dividend yields and payout ratio. As there are other factors that influence the share price, so therefore the study also consider some control variables to overcome such problem, the following control variables are included in the regression equation. The following multiple regression equation would be adopted to develop a relationship between share price and dividend policy.

$\mathrm{Y}_{\mathrm{it}}=\beta_{1} \mathrm{SD}_{\mathrm{it}}+\beta_{2} \mathrm{RR}_{\mathrm{it}}+\beta_{3} \mathrm{DPR}_{\mathrm{it}}+\beta_{4} \mathrm{PAT}_{\mathrm{it}}+\beta_{5} \mathrm{EPS}_{\mathrm{it}}+\beta_{6} \mathrm{ROE}_{\mathrm{it}}+\alpha_{\mathrm{i}}+\mu_{\mathrm{it}}$

Where;

$\alpha_{i},(i=1 \ldots n)$ shows the unknown intercept for every entity (n entity - specific intercepts)

$\beta_{1} \mathrm{SD}_{\mathrm{it}}=$ Coefficient of Stock dividend per share,

$\beta_{2} \mathrm{RR}_{\mathrm{it}}=$ Retention ratio,

$\beta_{3} \mathrm{DPR}_{\mathrm{it}}=$ Dividend payout ratio,

$\beta_{4} \mathrm{PAT}_{\text {it }}=$ Profit after tax,

$\beta_{5} \mathrm{EPS}_{\mathrm{it}}=$ Earnings per share,

$\beta_{6} \mathrm{ROE}_{\mathrm{it}}=$ Return on equity,

$\mu_{\mathrm{it}}=$ Error term in the equation,

$\mathrm{i}=\mathrm{ith}$ company

$\mathrm{t}=$ time period. 


\subsection{Theoretical Framework:}

Independent Variable

Dependent Variable

\begin{tabular}{|l|l|l|}
\hline Stock Dividend per share & Stock Market \\
\hline Retention Ratio & & \\
\hline Dividend Payout Ratio & \\
\hline
\end{tabular}


Table No3.1 Variables taken for the effect of dividend policy on stock prices

\begin{tabular}{|c|c|c|c|c|}
\hline S. No. & Variable & Symbol & Formula & Measurement \\
\hline 1 & Stock dividend per share & SD & Dividends/Number of shares & Rs \\
\hline 2 & Retention ratio & RR & (Net Income-Dividends)/Net Income & $\%$ age \\
\hline 3 & Dividend payout ratio & DPR & Dividends/Net Income & $\%$ age \\
\hline 4 & Profit after tax & PAT & Gross Profit - Operating expenses - & Rs \\
\hline 5 & Earnings per share & EPS & $\begin{array}{c}\text { Interest - Taxes } \\
\text { shareholders/No of Equity Shares }\end{array}$ & Rs \\
\hline 6 & Return on equity & ROE & (Net Income/Stockholder's Equity) 100 & $\%$ age \\
\hline
\end{tabular}

\subsection{Variables}

This study is aimed at to check whether dividend policy has any effect on stock prices or not. This study has a total of seven variables out of which three variables are independent, three are control variables while one is dependent variable. Dependent variable include dividend per share, retention ratio and dividend payout ratio while control variables include profit after tax, earnings per share and return on equity. The only dependent variable of the study is stock market prices.

\subsubsection{Stock Dividend per Share (SD)}

Stock dividend per share of a firmmay be defined as total stock dividends divided by the number of outstanding shares. This variable is used as an independent variable. Akbar \&Baig (2010) used stock dividends as a variable so that its effect on stock prices. They came to know that there exists a direct relation between stock dividends and share market prices. Their study also results further specified stock dividend to be acentral variable that considerablyclarifies the deviations in the value of any firm's stock prices. Stock dividend can be calculated with the following formula. 


\section{DPS= Dividends/Number of shares}

\subsubsection{Retention Ratio (RR)}

Retention ratio is totally contraryto dividend payout ratio. This ratio can be assessed by deductingthe total value of dividends out of any firm's earnings. This variable is used as an independent variable. Retention ratio may be termed as the percentage of a firm's incomes that is not distributed out in the form dividends rather credited to retained earnings. Retention ratio is also called plough back ratio. Pani (2008) used the variable of retention ratio to see whether there exists anyinfluence on stock prices. Their study proposeda direct relationship between the two. Retention ratio of any firm can be found with the help of following formula.

\section{Retention Ratio $=($ Net Income-Dividends $) /$ Net Income}

\subsubsection{Dividend Payout Ratio (DPR)}

Dividend payout ratio is the relative amount of profit distributed by any firm in the form of dividends to the total amount of net income of any business. The amount out of the total earnings of any organization, that is not distributed as a dividend to the shareholders is utilized by any firm for the purpose of growth. This amount kept by any firm for the purpose of reinvestment in the same firm is called retained earnings.This variable is used as an independent variable. Dividend payout ratio may be calculated through following formula.

\section{DPR=Dividends/Net Income}

Observation of the dividend payout ratio's formula gives an idea that net income can be found on the company's profit and loss account. Investors keep an eye on dividend payout ratio at the time of decision making whether to purchase shares of a profit making dividend distributing companyor of profit generating corporation with high growth future prospects. In nut shell, dividend payout ratio considers stable revenue and reinvestment for potential forthcoming earnings.

\subsubsection{Profit after Tax (PAT)}

In this study profit after tax has been used as a control variable. Al-Kuwari (2010) has already used profit after tax as an independent variable in his studies who came to know that there exists a direct relationship in stock prices and profit after tax. In their study profit after tax has been used as an important variable able to describe the deviations in the value of stock prices of any given company. In short for the purpose of calculation of net profit after tax cost 
of goods sold, all operating expenses, interest and taxes all are deducted fromthe respective firm's sales revenue. For the calculations' understanding the format of the income statementshould be compulsorily properly and thoroughly looked into. Formula of the profit after taxes may be as under:

$$
\text { PAT }=\text { Gross Profit }- \text { Operating expenses }- \text { Interest }- \text { Taxes }
$$

\subsubsection{Earnings per Share (EPS)}

Value of earnings per share can be calculated by deducting dividend that is paid on preferred stocks out of the net income and dividing the resultant value with the number of outstanding shares. Reason for its being selected that earning per share is reflected as asign of determining the ability of the firms to earn profit. Huang and Cheng (2009) used earnings per share as a control variable in their studies. This variable is used as a control variable.

EPS $=$ Net Profit available for equity shareholder/No of Equity Shares

In the light of generally accepted accounting principles (GAAP), publicly owned firms are supposed to show earnings per share next to the income line in their respective profit and loss accounts. Earnings per share has its own distinct position in financial ratios.

\subsubsection{Return on Equity (ROE)}

Return on equity can be calculated by dividing the firm's value of profit after tax with shareholders' equity. Ling et al., (2008) also used this variable in his study. Theyestablished a direct relationship between return on equity and stock prices. In this study this variable is used as a control variable. Value of return on equity cab be calculated through dividing the value of net income by stockholders' equity.

$$
\mathrm{ROE}=(\text { Net Income/Stockholder's Equity })^{*} 100
$$

Return on equity is a meter of firm's ability to earn profits by assessing the amount a company makes through the investments by the shareholders. For the purpose of calculation of return on equity net income value can be weighed for the respective firm's full fiscal year next to payment of taxes and dividend to preference shareholders and prior to disbursing common stock dividends. Preferred stocks are excluded from shareholders' equity of any firm.. 


\subsubsection{Stock Market Prices}

In this study the stock market price has been used as a dependent variable. Stock market prices can be calculated through the process of considering closing market prices of shares.Ebrahim and Amir (2009) had also used stock market prices as a dependent variable.

According to Yasir Habib et al. (2012) dividend yield, has a positive association with stock prices, Khan and Khan (2011), dividend yield, profit after tax, earnings per shares and return on equity has direct association with stock prices. Kanwal Iqbal Khan (2011) stated that dividend yield, profit after tax, earnings per shares and return on equity has direct while retention ratio has negative associations with stock prices. So in this study it is predictable that all the dividend yield, profit after tax, earnings per shares and return on equity will havesignificant associationwith stock prices while value of retention ratio being dependent on the perception of shareholders will be either positively or negatively connected to stock prices. If stockholdersthink that companies have attractive investment chances inside then retention ratio will be directly related to stock prices. On the other hand if financiershave better and money-making investment prospectsexternalto the respective company thenretention ratio will be indirectly linked to stock prices.

\section{RESULTS AND DISCUSSION}

In this section it is attempted to estimate our proposed model. Here four different sets of regression results are shown. Before applying pooled regression the data was diagnosed, this study used Breusch-Pagan test to examine the heteroscedascity and results show that data is homo or in other words there is no heteroscedascity problem.In pooled OLS regression there was complete multi colliniarity between the two variables; that is the dividend payout ratio and retention ratio. Therefore pooled OLS regression with all variables and pooled OLS results without retention ratio are shown just for the sake of comparison. The nature of data is panel. Panel data are usually tested, by using fixed effect and random effect models of regression analysis. Later on, Hausman test was applied to check whether to focus fixed effect or random effect results. As the P-value of Hausman test was more than 0.05 that is why finally random effect results were chosen for interpretation. 
Table No 4.1 Pooled Regression Results of variables taken for the effect of dividend policy on stock prices

\begin{tabular}{|c|c|c|c|c|c|c|}
\hline Variable & $\begin{array}{c}\text { Co- } \\
\text { efficient }\end{array}$ & $\begin{array}{l}\text { Std. } \\
\text { Error }\end{array}$ & P-Value & t-Statistics & $\mathbf{R}^{2}$ & F-Value \\
\hline DPS & -0.170 & 0.280 & 0.542 & -0.610 & \multirow{6}{*}{0.570} & \multirow{6}{*}{106.950} \\
\hline $\mathbf{R R}$ & 0.046 & 0.047 & 0.330 & 0.975 & & \\
\hline DPR & 0.585 & 0.285 & $0.041 *$ & 2.054 & & \\
\hline EPS & 1.422 & 0.289 & $0.000 *$ & 4.925 & & \\
\hline PAT & -0.029 & 0.044 & 0.517 & -0.649 & & \\
\hline ROE & -0.905 & 0.057 & $0.000 *$ & -15.940 & & \\
\hline
\end{tabular}

Note:

In this table from left to right column 1 represents names of variables, 2 represents value for Co-efficient, 3 represents standard error, 4 represents P-value, 5 represents $T$-statistics, 6 represents $R^{2}$ and 7 represents $F$-value. Level of significance at 5\% is marked with *. While from top to bottom row 2 represents value for dividend per share (DPS), 3 represents for retention ratio $(R R), 4$ represents dividend payout ratio $(D P R), 5$ represents earning per share (EPS), 6 represents profit after tax (PAT) and 7 represents return on equity (ROE).

Table 4.1 show the details of descriptive statistical analysis and pooled regression results of non-financial KSE-100 indexed firms having positive profit and dividend payment throughout for a period of twelve years starting from 2001. Looking at results of P-value and T-Statistics it is very much clear that stock marketprice has directworth mentioningaffiliation with dividend payout ratio and earning per share while return on equity shows negative noteworthy relationship with stock market price. Whereas variables like dividend per share, retention ration and profit after tax have insignificant relationship. F-Value of the regression table signifies whether overall model is statistically significant or not. If F-value is greater than 4 then it shows that overall model is statistically significant. $\mathrm{R}^{2}=0.5695$ shows that almost $56.95 \%$ change in dependent variable is because of change in independent variables. 
Table No 4.2 PooledRegression Results of variables without Retention Ratio taken for the effect of dividend policy on stock prices

\begin{tabular}{|c|c|c|c|c|c|c|}
\hline Variable & $\begin{array}{c}\text { Co- } \\
\text { efficient }\end{array}$ & $\begin{array}{c}\text { Std. } \\
\text { Error }\end{array}$ & P-Value & T-Statistics & \multirow{2}{*}{$\mathbf{R}^{2}$} & \multirow{2}{*}{ F-Value } \\
\hline DPS & -0.188 & 0.279 & 0.500 & -0.675 & & \\
\cline { 1 - 5 } DPR & $\mathbf{0 . 5 7 9}$ & $\mathbf{0 . 2 8 5}$ & $\mathbf{0 . 0 4 2} *$ & $\mathbf{2 . 0 3 5}$ & \multirow{2}{*}{0.569} & \multirow{2}{*}{128.160} \\
\cline { 1 - 4 } EPS & $\mathbf{1 . 4 4 2}$ & $\mathbf{0 . 2 8 8}$ & $\mathbf{0 . 0 0 0} *$ & $\mathbf{5 . 0 0 7}$ & \\
\cline { 1 - 4 } PAT & -0.028 & 0.044 & 0.521 & -0.643 & & \\
\cline { 1 - 4 } ROE & $\mathbf{- 0 . 9 0 8}$ & $\mathbf{0 . 0 5 7}$ & $\mathbf{0 . 0 0 0 *}$ & $\mathbf{- 1 6 . 0 1 4}$ & & \\
\hline
\end{tabular}

\section{Note:}

In this table from left to right column 1 represents names of variables, 2 represents value for Co-efficient, 3 represents standard error, 4 represents P-value, 5 represents T-statistics, 6 represents $R^{2}$ and 7 represents $F$-value. Level of significance at $5 \%$ is marked with *. While from top to bottom row 2 represents value for dividend per share (DPS), 3 represents for dividend payout ratio (DPR), 4 represents earning per share (EPS),, 5 represents profit after tax (PAT) and 6 represents return on equity (ROE).

Table 4.2 show the details of descriptive statistical analysis and pooled regression results of non-financial KSE-100 indexed firms having positive profit and dividend payment throughout for a period of twelve years starting from 2001. Looking at results of P-value and T-Statistics it is very much clear that stock market price has directworth mentioning relationship with dividend payout ratio and earning per share while return on equity has negative significant relationship with stock market price. Whereas variables like dividend per share and profit after tax have insignificant relationship. In this case retention ratio is omittedautomatically in pooled regression test by the statapackage due to colliniarity between dividend payout and retention ratio. This ratio has been previously ignored by the scholars.Rather they either used dividend payout ratio or dividend yield ratio in their research 
for the purpose of explaining change in the value of stock price. Khan and Khan (2011). FValue of the regression table signifies whether overall model is statistically significant or not. If F-value is greater than 4 then it shows that overall model is statistically significant. Here Fvalue is equal to $128.16 . \mathrm{R}^{2}=0.5687$ shows that almost $56.87 \%$ change in dependent variable is because of change in independent variables.

In this study data are panel which is also recognized as longitudinal and crosssectional time-series data. Panel data have the capability to control the results for unobserved variables. These variables might include cultural factors or variations in organizational norms; variable whose value changes with the passage of time but not across similar organizations, countries, and states. One of the assumptions of the fixed effect model is that unique features of the entities oughtnot to be correlated with other distinct features. If the error terms are correlated then fixed effect is not considered a fit choice and the results may not be trustworthy and as a result random-effects will have to be used. The logical reason on the back of usage of the random effects model is that, in contrary to the fixed effects model, the variation in entities is assumed to be random and unrelated with the independent variables of the model. One of the merits of random effects is that invariable variables may be included. In fixed effects model these variables are absorbed by the intercept.

\section{Table No 4.3 Fixed Effect Regression Resultsof variables taken for the effect of dividend policy on stock prices}

\begin{tabular}{|c|c|c|c|c|c|c|}
\hline Variable & $\begin{array}{c}\text { Co- } \\
\text { efficient }\end{array}$ & $\begin{array}{l}\text { Std. } \\
\text { Error }\end{array}$ & P-Value & T-Statistics & $\mathbf{R}^{2}$ & F-Value \\
\hline DPS & -0.223 & 0.296 & 0.451 & -0.754 & \multirow{6}{*}{0.569} & \multirow{6}{*}{98.080} \\
\hline $\mathbf{R R}$ & 0.046 & 0.049 & 0.342 & 0.951 & & \\
\hline DPR & 0.623 & 0.301 & 0.039* & 2.071 & & \\
\hline EPS & 1.469 & 0.306 & $0.000 *$ & 4.804 & & \\
\hline PAT & -0.024 & 0.047 & 0.607 & -0.515 & & \\
\hline ROE & -0.920 & 0.059 & $0.000 *$ & -15.506 & & \\
\hline
\end{tabular}

\section{Note:}


In this table from left to right column 1 represents names of variables, 2 represents value for Co-efficient, 3 represents standard error, 4 represents P-value, 5 represents $T$-statistics, 6 represents $R^{2}$ and 7 represents $F$-value. Level of significance at 5\% is marked with *. While from top to bottom row 2 represents value for dividend per share (DPS), 3 represents for retention ratio $(R R), 4$ represents dividend payout ratio $(D P R), 5$ represents earning per share (EPS), 6 represents profit after tax (PAT) and 7 represents return on equity (ROE).

Table 4.3 show the details of descriptive statistical analysis and fixed effect results of non-financial KSE-100 indexed firms having positive profit and dividend payment throughout for a period of twelve years starting from 2001. Looking at results it is very much clear that stock market price has positively significant relationship with dividend payout ratio and earning per share while return on equity shows negatively noteworthy relationship with stock market price. Whereas variables like dividend per share, retention ratio and profit after tax have insignificant relationship. F-Value of the regression table signifies whether overall model is statistically significant or not. If F-value is greater than 4 then it shows that overall model is statistically significant. Here $F$-value is equal to $98.08 . \mathrm{R}^{2}=0.5694$ shows that almost $56.94 \%$ change in dependent variable is because of change in independent variables.

Table No 4.4 Random Effect RegressionResults of variables taken for the effect of dividend policy on stock prices

\begin{tabular}{|c|c|c|c|c|c|c|}
\hline Variable & $\begin{array}{c}\text { Co- } \\
\text { efficient }\end{array}$ & $\begin{array}{c}\text { Std. } \\
\text { Error }\end{array}$ & P-Value & T-Statistics & $\mathbf{R}^{2}$ & F-Value \\
\hline DPS & -0.170 & 0.280 & 0.542 & -0.610 & \multirow{6}{*}{0.570} & \multirow{6}{*}{641.700} \\
\hline $\mathbf{R R}$ & 0.046 & 0.047 & 0.329 & 0.975 & & \\
\hline DPR & 0.585 & 0.285 & $0.040 *$ & 2.054 & & \\
\hline EPS & 1.422 & 0.289 & $0.000 *$ & 4.925 & & \\
\hline PAT & -0.029 & 0.044 & 0.517 & -0.649 & & \\
\hline ROE & -0.905 & 0.057 & $0.000 *$ & -15.940 & & \\
\hline
\end{tabular}

\section{Note:}

In this table from left to right column 1 represents names of variables, 2 represents value for Co-efficient, 3 represents standard error, 4 represents P-value, 5 represents $T$-statistics, 6 
represents $R^{2}$ and 7 represents F-value. Level of significance at 5\% is marked with *. While from top to bottom row 2 represents value for dividend per share (DPS), 3 represents for retention ratio $(R R), 4$ represents dividend payout ratio $(D P R), 5$ represents earning per share (EPS), 6 represents profit after tax (PAT) and 7 represents return on equity (ROE).

For the purpose of decision making regarding choice between fixed and random effects Hausman test was run. The decision of choice between fixed and random effect is based on p-value of Hausman test. If the p - value of the Hausman test is less than 0.05 , we have a preference to use a fixed effects model. On the other hand if the p-value of the Hausman test is more than 0.05 , we select to use random effects. In my case the p-value of Hausman test was more than 0.05 so random effects are used. For comparison purpose pooledregression results are also given.

Table 4.4 highlights the value of Wald chi square test (F-value) equal to 641.70. This value may be shown as F-Value. "F" value of the table signifies whether the overall model is statistically significant or not. The more the F value or Wald chi square test value the more the model is considered significant. Here Wald chi square test value is 641.70 showing that in general the model is significant. $\mathrm{R}^{2}=0.5695$ shows that $56.95 \%$ change in dependent variable is because of change in independent variables.

This table highlights the relevance or irrelevance of each variable of the study. Results witness that dividend per share shows insignificant relation toward share market prices. Pvalue shows the level of significance. It is evident from the random effect results that level of significance is insignificant at $5 \%$. This result is also supported by t-statistics as its value is less than \pm 2 .Its reason might be that investors regard stock dividend per share as a hint of increased profit for the coming period(s). This might be due to the fact that dividend per share means outflow of cash for the business. More outflows of cash in the form of dividend signify that the organization lacks profitable reinvestment of funds. The organization management is assumed by existing and prospective shareholders to face either lack of opportunities for further investment or lack of interest in plowing back of profits in business. Another possible reason may be that the increased amount of dividend per share means more income for shareholders causing an increase in their rates of tax. Many researchers like Travlos, Trigeorgis, and Vafeas (2001) and Akbar and Baig (2010), Khan and Khan (2011) found the positive relation between them. This is because of the element that firms' dividend incomes being distributed are hoping to move upward. The more dividends mean more earnings for investors which will rise the demand of investors for the purchase of firm's shares in the market finally causing addition to the market price of shares. Its reason might be that 
investors regard stock dividend per share as a hint of increased profit for the coming period(s). Results prove bird-in-hand theory. In short we can say that null hypothesis cannot be rejected.

Looking at the results it is clear that retention ratio has a not worth mentioning association with stock prices. It is evident from the results that level of significance at $5 \%$ significance level. This positive association is due to the fact that profit distributed in the form of dividend is taxed twice while the profit retained in the business is not taxed. This profit is re-invested in the business and as a result causes share prices to increase. Another reason might be the size of the investors of the firm. If the owners of a firm are mostly large then they are interested in capital gains whereas small investors do not like to receive capital gains, rather they like to receive dividend. Capital gain is the profit on share earned by shareholders due selling of the shares whose selling price was more than their purchase price. It is worth mentioning here that capital gain is taxable in Pakistan since July 2012. But as mentioned earlier that the data is related to a period of twelve years from 2001 till 2012 therefore it is concluded that those shareholders who will sell their shares will get Capital Gain which is not taxable profit of the shareholders. In case of Pani (2008) there was also positive association in retention ratio and stock prices. In case of Auther and Kawal (2011) there was a negative association between the two. This negative association could be because of the fact that shareholders have better profit giving investment opportunities due to which they like their firms to pay them dividends rather than retaining profit in the business. Whenever firms keep hold of that earned profits of the companies for the sake of meeting their internal needs; share prices decrease. As a result alternate hypothesis is accepted.

Dividend payout ratio has positive significant relation to share prices. A $1 \%$ change in the value of dividend payout ratio it causes a change of $0.5848 \%$ in the value of the share market price. Here the relationship is positive, meaning that an increase in the value of dividend payout ratio will cause an increase in the value of the share market price and vice versa. P-value shows the level of significance. It is evident from the results that level of significance is insignificant at $5 \%$ level. This result is similar to results of Allen and Rachim (1996), Rashid and Rahman (2009) and Nazir et al., (2010), Hussainey et al., (2011).WhereasNishat and Irfan (2003) and Asghar et al., (2011) got a direct relationship between stock market prices and dividend payout ratio.

Profit after tax, earning per share and return on equity are the three control variables. Profit after tax has immaterial relation to stock prices. This relationship is negative. In other 
words we may say that any profit after tax has indirect relationship. P-value shows the level of significance. It is evident from the random effect results that level of significance is insignificant at 5\% significance level. In case of Autherand Kanwal (2011); who used it as a control variable, there was a positive association between the two. In the studies of Pani (2008), Adesola and Okwong (2009), Ahmed and Javid (2009) and Al-Kuwari (2010) worked on profit after tax as independent variable where there was a positive relationship between stock prices and profit after tax. Earnings per share have a positive significant relation to stock prices. A $1 \%$ change in earnings per share will bring $1.4218 \%$ change in the value of stock market price of the companies. This relationship is positive. In other words we may say that any profit after tax has a direct relationship. If the value of the proft after tax increases it causes a growth in the firm'smarket value of the share. P-value shows that level of significance. It is evident from the Random Effect results that level of significance is significant at 5\% significance level. Same was the result with Baskin (1989), Allen and Rachim (1996), Liu and Hu (2005), Adefila et al., (2004), Adesola and Okwong (2009) and Chen et al., (2009).

There is negative significant relation between return on equity and share prices. A $1 \%$ change in return on equity will bring $0.9054 \%$ change in the value of stock market price of the companies. This relationship is negative. In other words we may say that any return on equity has an indirect relationship. If the value of the earnings per share increases it causes a decrease in the value of the share market price of the organization. P-value shows that level of significance. It is evident from the random effect results that level of significance is significant at all 1\%,5\%,10\% significance levels. Negative association between stock prices and return on equity shows that when an organization is not professionally using shareholders' funds and generate less proceeds for investment ultimately causing decrease in share prices and vice versa. According to Liu and Hu (2005), Raballe and Hedensted (2008) and Ling et al., (2008) results there was a positive association between return on equity and stock prices.

\section{SUMMARY, CONCLUSION AND RECOMMENDATIONS}

\subsection{Summary}

The central intention of this study is to observe the association linking dividend policy and stock prices. Research questions of the study are whether dividend policy has an impact 
on stock prices or not? The objectives of the study are to study the relationship of the dividend policy with the share prices and validate or disprove the academic explanation of the practice of paying dividend. Though the simple OLS regression analysis is initially used, but due to the reason of the data being panel, fixed and random effects of regression analysis are used. Hausman test is used to decide whether to focus the results of fixed or random effect. As the P-value of the Hausman test is more than 0.05 that is why the random effect is focused. Results show that out of the variables only earning per share and dividend payout ratio have a significant positive relationship while return on equity has negative significant relationship with the dependent variable. On the other hand all other variables, i.e. dividend per share, retention ratio and profit after tax have an insignificant relationship with stock market price.

\subsection{Conclusion}

The study is conducted to know the impact of dividend policy on stock prices. Results of the random effect shows that among the given variables only dividend payout ratio, earning for each share ratio and return on equity have statistically significant relationship with stock market price. One percent growth in dividend payout ratio will cause $0.5848 \%$ rise in stock market price and one percent decline in dividend payout ratio will cause $0.5848 \%$ fall in stock market price. Similarly one out of hundred rises in the value of earning per share will result in $1.4218 \%$ upward movement in the value of stock market value. On the other hand one per hundred upturn in the value of return on equity will cause $0.9054 \%$ drop in the value of stock market prices and inverse will be the results in inverse situation. Unlike above mentioned variables dividend per share, retention ratio along with profit after tax show statistically minor relationship towards stock market price.

\subsection{Recommendations}

On the basis of this study it is recommended that:

1) For firms in the sample it is suggested that companies should observe regular payment of dividend. It will cause an increase in the stock market prices. On the other hand profit retention by firms will cause a decline in the value of stock market prices.

2) The value of a rupee earned through debt is valued higher than a dollar earned through equity.

3) Researchers on this topic should try to increase the number of firms and number of periods for which data will be analyzed. 
4) As owners and managers are interested in the change in stock market price so, through this study they respectively may get a guidance regarding the factors that causes change in stock market prices and elements considered influential by investors in decision making at the time of investment.

5) Besides, this study also pinpoint key elements for directors in framing their firm's respective dividend policy. This reading has several restrictions. Restrictions of this study may be used as a gateway to possibilities for advanced research in the same area in the future. The restrictions and their respective suggestions may include:

6) More research is advised to inquire about and add in other factors regarding dividend policy.

7) Furthermore researchers are suggested to think about different research design to make sure the importance of all dividend theories in Pakistani context.

\section{LITERATURE CITED}

Adefila et al. 2004. The Effect of Dividend Policy on the Market Price of Shares in Nigeria: Case Study of Fifteen Quoted Companies. International Journal of Accounting. University of Ado-Ekiti. 2 (1):1-10.

Adefilaet al., 2004. The Effect of Dividend Policy on the Market Price of Shares in Nigeria: Case Study of Fifteen Quoted Companies. International Journal of Accounting. University of Ado-Ekiti. 2 (1):82-91.

Adesola, W. A. and A. E. Okwong. 2009. An Emparical Study of Dividend Policy of Quoted Companies in Nigeria. Global Journal of Social Sciences. 8 (1):85-101.

Afza, T. and H. H. Mirza, 2010. Ownership Structure and Cash Flows As Determinants of Corporate. International Business Research. 3(3): 210-221.

Ahmed, H. and Javid, A. 2009. Dynamics and Determinants of Dividend Policy in Pakistan (Evidence from Karachi Stock Exchange Non-Financial Firms). International Journal of Finance and Economics. 25: 148-171.

Akbar, M and Baig, H. H. Summer 2010. Reaction of Stock Prices to Dividend Announcements and Market Efficiency in Pakistan. The Lahore Journal of Economics. 15(1):103-125.

Allen, D. E. and V. S. Rachim, 1996. Dividend Policy and Stock Price Volatility: Australian Evidence. Applied Financial Economics. 6 (2):175-188. 
Al-Kuwari, D. 2010. To Pay or Not to Pay: Using Emerging Panel Data to Identify Factors Influencing Corporate Dividend Payout Decisions. International Research Journal of Finance and Economics. 42, 19-36.

Amidu, M. 2007. How does dividend policy affect firm performance? A Ghanaian Case. Investment management and Financial innovations. 4(2):103-112.

Anand, M. 2008. Factors Influencing Dividend Policy Decisions of Corporate India. The ICFAI Journal of Applied Finance. 10 (2):5-16.

Asquith, P. and D. Mullins. 1983. The impact of initiating dividends on shareholder wealth, Journal of Business. 56: 77-96.

Baker, H. K. et al., 2002. Revisiting Managerial Perspectives on Dividend Policy. Journal of Economics and Finance. (26):267-283.

Baker. et al., 2006 In search of a residual dividend policy. Review of Financial Economics. (15): 1-18. Barclay, M.J., and C.W. Smith. 1995. Financial Architecture: Leverage, Maturity and Priority, Journal of Applied Corporate Finance. 8(4): 4-17.

Baskin, J. (1989). Dividend Policy and the Volatility of Common Stock. Journal of Portfolio Management. 3 (15):19-25.

Benartzi, S. et al., 1997. Do Changes in Dividends Signal the Future or the Past? Journal of Finance. 3 (52):1007-1034

Black, F., and M. Scholes. 1973. The Pricing of Options and Corporate Liabilities. Journal of Political Economy. 81 (3): 637-654.

Black, F. and M. Scholes. 1974. The Effects of Dividend Yield and Dividend Policy on Common Stock Prices and Returns. Journal of Financial Economics. 1 (1):1-22.

Capstaff, J. et al., 2004. Share Price Reaction to Dividend Announcements: Empirical Evidence on the Signaling Model from the Oslo Stock Exchange. Multinational finance Journal. 8 (1 \& 2):115-139.

Chen, D.-H. et al. 2009. The Announcement Effect of Cash Dividend Changes on Share Prices: An Empirical Analysis of China. The Chinese Economy. 42(1): 62-85.

Chen, G.et al. 2002. The Information Content of Concurrently Announced Earnings, Cash Dividends, and Stock Dividends: An Investigation of the Chinese Stock Market. Journal of International Financial Management and Accounting. 2 (13):101-124.

Chen, J. and N. Dhiensiri. 2009. Determinants of Dividend Policy: The Evidence from New Zealand. International Research Journal of Finance and Economics. (34):18-28.

Chen, D.-H., Huang, H.-H. L., \& Cheng, T. (2009). The Announcement Effect of Cash Dividend Changes on Share Prices: An Empirical Analysis of China. The Chinese Economy, 42 (1), 6285. 
Davis, J. S. 1917. Essays in the Earlier History of American Corporations (1-2). Cambridge: MA: Harvard University Press.

DeAngelo, H. and L.DeAngelo. 2007. Payout policy pedagogy: what matters and why? European Financial Management. 13(1): 11-27.

Denis, D. J. and I. Osobov. 2008. Why Do Firms Pay Dividends? International Evidence on the Determinants of Dividend Policy. Journal of Financial Economics. 89 (1):62-82.

Dong, M. et al., 2005. Why Individual Investors Want Dividends. Journal of Corporate Finance. 1 (12):121-158.

Easterbrook,F.H. 1984. Two agency-cost explanations of dividends. The American Economic Review, (74): 650-9.

Gorden, M. J. 1963. Optimal Investment and Financing Policy. The Journal of Finance. 18 (2):264272.

Gordon, M.J. and Shapiro, E. 1956. Capital equipment analysis: the required rate of profit. Management Science, Vol. 3: 102-10.

Ho, H. (2002). Dividend policies in Australia and Japan. International Advances in Economics.2 (9):91-100.

Hussainey, K. et al., 2011. Dividend Policy and Share Price Volatility: UK Evidence. Journal of Risk Finance. 12 (1):57-68.

Jensen, M. and W. Meckling. 1976. Theory of the firm: Managerial behavior, agency costs, and wnership structure. Journal of Financial Economics 3(4): 305-60.

John, K. and J. Williams. 1985. Dividends, Dilution and Taxes: A Signaling Equilibrium. Journal of Finance. 4 (40):1053-1070.

Kaen and F.R. 2003. A blueprint for corporate governance: strategy, accountability, and the preservation of shareholder value. New York: AMACOM.

Khan, A. and K. Khan. 2011Dividend Policy and Stock Prices - A Case of KSE-100 Index Companies.

Khan, K. I. 2011. Effect of Dividends on Stock Prices- A Case of Chemical and Pharmaceutical Industry of Pakistan University of Central Punjab, Lahore. 6(6): 969-978.

Khan, N.U. 2011. Dividend policy and the stock market reaction to dividend announcements in PakistanUniversity of Dundee UK. 120-123.

Ling, F. S. et al., 2008. Dividend Policy: Evidence From Public Listed Companies in Malaysia. International Review of Business Research Papers. 4 (4):208-222. 
Lintner, J. 1956. Distribution of Incomes of Corporations Among Dividends, Retained Earnings, and Taxes. American Economic Review. 46: 97-113.

Liu, S., and Y. Hu. 2005. Empirical Analysis of Cash Dividend Payment in Chinese Listed Companies. Nature and Science. 1 (3): 65-70.

Maditinos, D. I. et al., 2007. Individual Investors' Perceptions towards Dividends: The Case of Greece. International Journal of Monetary Economics and Finance. 1 (1):18-31.

Miller, M. H. and F. Modigliani. 1961. Dividend Policy, Growth and Valuation of shares.Journal of Business . 4 (34): 411-433

Miller, M. H. and K. Rock. 1985. Dividend Policy Under Asymmetric Information. The Journal of Finance. 40 (4): 1031-1051.

Myers, M. and F. Bacon, 2004. The Determinants of Corporate Dividend Policy. Academy of Accounting and Financial Studies Journal. 3 (8):17-28.

Naeem, S. and M. Nasr, 2007. Dividend Policy of Pakistani Firms: Trends and Determinants. International Review of Business Research Papers. 3(3): 242-254.

Nazir, et al., 2010. Determinants of Stock Price Volatility in Karachi Stock Exchange: The Mediating Role of Corporate Dividend Policy. International Research Journal of Finance and Economics (55): 100107.

Nazir, M. S. 2010. Determinants of Stock Price Volatility in Karachi Stock Exchange: The Mediating Role of Corporate Dividend Policy. International Research Journal of Finance and Economics. (55):100-107.

Nishat, M. 1992. Share Prices, Dividend and Retained Earnings Behavior in Pakistan Stock Market. The Indian Economic Journal. 40 (2): 57-65.

Nishat, M. 1995. Determinants of stock prices in Pakistan. International Journal of Development Banking. 13(2): 37-42.

Nishat, M. 1999. The Impact of Institutional Development on Stock Prices in Pakistan. Doctoral Dissertation, Auckland Business School, University of Auckland.

Nishat, M. 2001. Industry risk premia in Pakistan. Pakistan Development Review. 40 (4): 929-952.

Nishat, M., and C. M. Irfan, 2003. Dividend Policy and Stock Price Volatility in Pakistan. $11^{\text {th }}$ Pacific Basin Finance, Economics and Accounting Conference.

Nishat, M. and N. Bilgrami. 1994. Who pays dividend - An exploratory analysis of firms listed with Karachi stock market", Saving and Development. (3): 17. 
Pani, U. 2008. Dividend Policy and Stock Price Behaviour in Indian Corporate Sector: A panel data approach. Retrieved from Indian Institute of Technology: http://ssrn.com/abstract=1216171

Pradhan, R. S. 2003. Effects of Dividends on Common Stock Prices: The Nepalese Evidence. Research in Nepalese Finance. 1-13.

Raballe, J., and J. S. Hedensted. 2008. Dividend Determinants in Denmark. Retrieved from: http://papers.ssrn.com

Rashid, A., and A.Z.M.A. Rahman. 2009. Dividend Policy and Stock Price Volatility: Evidence from Bangladesh. Journal of Applied Business and Economics. 71-81.

Rozeff, M. 1982. Growth, beta and agency costs as determinants of dividend payout ratios. Journal of Financial Research 5(3): 249- 259.

Travlos, N. et al., 2001. Shareholder Wealth Effects of Dividend Policy Changes in an Emerging Stock Market: The Case of Cyprus. Multinational Finance Journal. 5 (2):87-112.

Uddin, M. H. and G. M.Chowdhury. 2005. Effects of Dividend Announcement on Shareholders' Value: Evidence from Dhaka Stock Exchange. Journal of Business Research. 7:61-72.

Yasir, Habib et al(2012). Dividend Policy and Share Price Volatility: Evidence from Pakistan. Global Journal of Management and Business Research, 12(5) 